\title{
Embryological considerations on the bilateral reversed palmaris longus muscle: a case report in human
}

\author{
Heck, L. ${ }^{1}$ and Campos, D. ${ }^{1,2 *}$ \\ ${ }^{1}$ Course of Medicine, Department of Biology and Pharmacy, University of Santa Cruz do Sul - UNISC, \\ Av. Independência, 2293, CEP 96815-900, Santa Cruz do Sul, RS, Brazil \\ ${ }^{2}$ Biological Sciences Course, Department of Biology and Pharmacy, University of Santa Cruz do Sul - UNISC, \\ Av. Independência, 2293, CEP 96815-900, Santa Cruz do Sul, RS, Brazil \\ *E-mail: dcampos@unisc.br
}

\begin{abstract}
This study describes a rare case of bilateral reversed palmaris longus muscle. An unusual variation was observed during the male cadaver dissection (60-year-old White). According to the literature, a reversed palmaris longus muscle may cause a compartment syndrome in the wrist area, carpal tunnel, and Guyon's syndrome. Moreover, this particular variation of the reversed palmaris longus muscle is rarely reported and has the potential to cause compression of both the median and ulnar nerves. Thus, the described variation is also useful to the hand surgeon, as the anomalous muscle is an anatomical landmark for operations at this area. Morphological variability and clinical significance are reviewed.
\end{abstract}

Keywords: reversed palmaris longus muscle, bilateral, embryology, human.

\section{Introduction}

All muscles are subjected to a certain amount of variations, but some are more affected than others (MOORE and PERSAUD, 2004). The palmaris longus (PL) is one of the most variable muscles in the human body (RAOUF, KADER, JARADAR et al., 2013) and has been phylogenetically classified as a retrogressive muscle; i.e., a muscle with a short belly and a long tendon (KOO and ROBERTS, 1997).

The PL is often described as one slender and fusiform muscle, with a short belly proximally and a long tendon which passes anteriorly and distally in the forearm of the upper limb of humans and disposed medially to the flexor carpi radialis. This muscle has origin in the medial epicondyle of the humerus with insertion predominantly into central palmar surface of the aponeurosis and flexor retinaculum. It is innervated by median nerve and irrigated by branches from anterior ulnar recurrent arteria (MOORE, DALLEY and AGUR, 2011).

The PL may have a proximal tendon or a distal one. It may be fleshy distally and tendinous proximally (Palmaris longus inversus), being known as the reversed Palmaris longus muscle (RPL). Additionally, a RPL can cause median nerve compression, and less frequently, ulnar nerve compression (FAZAN, 2007).

The importance of continuing to record and discuss anatomical anomalies was addressed recently by Hicks and Newell (1997) in the light of technical advances and interventional methods of diagnosis and treatment. As mentioned by Khaledpour and Schindelmeiser (1994) the knowledge of such variations supplements the body of information about the muscles of the antebrachial and carpal regions and may be important for hand surgeons.

Furthermore, the anomalies, agenesis, variations and polymorphic presentation of the PL, coupled with its biomechanical role in the performance of flexion and supination through distal articulations in the upper limb, have formed the base for many studies found in medical literature (PAI, PRABHU, NAYAK et al., 2008).

Thus, in this report, we describe a rare case of bilateral RPL and discuss some embryological aspects of this anatomical variation.

\section{Case Report}

In the present study, we report a rare case of bilateral RPL. During the regular dissection in a 60 -year-old White male cadaver belonging to the didactical collection of the Laboratory of Human Anatomy at the University of Santa Cruz do Sul - Brazil, we detected that in both forearms PL was in the reverse position. The muscle was tendinous in its upper portion and muscular in its lower portion in both arms with considerable differences between the length of their tendons (see arrows, Figure 1). The whole anterior area of the right and left forearm was exposed with a dissection magnifying glass (ALLZWECK - LUPENLEUCHTE [1.75/2.25 magnification]). Muscle tendon, thickness and belly measurements were taken with the aid of a digital pachymeter (Digimess $\left.{ }^{\circledR}\right)$.

The right PL presents a muscular belly of $21 \mathrm{~cm}$ of length by $1.6 \mathrm{~cm}$ of width and $0.5 \mathrm{~cm}$ of thickness, presenting a tendon of $3 \mathrm{~cm}$ of length with a diameter of $0.4 \mathrm{~cm}$ (Figure 1 ). On the other hand, the left PL presents a muscular belly of $15 \mathrm{~cm}$ of length by $1.5 \mathrm{~cm}$ of width and $0.6 \mathrm{~cm}$ of thickness, presenting a tendon of $11 \mathrm{~cm}$ of length with a diameter of $0.5 \mathrm{~cm}$ (Figure 1). In our observations we didn't find any indication of associated pathology this anatomical variation.

\section{Discussion}

The PL muscle exhibits significant anatomical variance compared with other muscles of the upper extremity. The most frequent variation is complete absence of the muscle, 

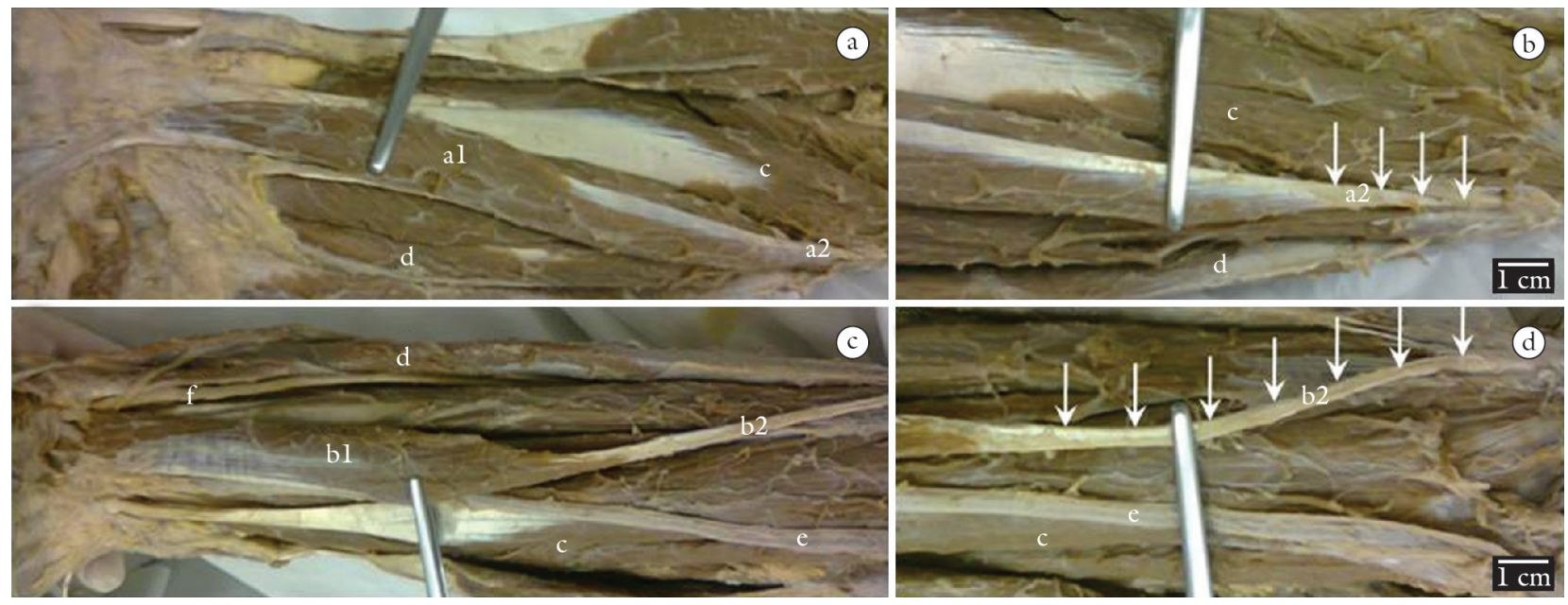

Figure 1. Photograph showing the right $(\mathrm{A}$ and $\mathrm{B})$ and the left $(\mathrm{C}$ and $\mathrm{D})$ reversed palmaris longus muscle. al) right reversed palmaris longus muscle, a2) right reversed tendon of palmaris longus, b1) left reversed palmaris longus muscle, b2) left reversed tendon of palmaris longus, c) flexor carpi radialis muscle, d) flexor carpi ulnaris muscle, e) radial artery, f) ulnar nerve. Arrows ( $\downarrow$ ) indicate the itinerary of the tendon of the reversed palmaris longus muscle with a considerable difference between the length of the tendons.

but a number of other variations exist (PARK, NAMDARI and YAO, 2010).

Among vertebrates PL is restricted to mammalian and well developed in species that use load to walk, for exemple: the PL is always present in orangutans, but is variably absent in chimpanzees and gorillas. In human beings the $\mathrm{PL}$ is considered by many authors as tensor of the palmar aponeurosis and eventually contributing to carpal flexion (ANGELINI JÚNIOR, ANGELINI, OLIVEIRA et al., 2012).

Morphogenetically developed and regulated by a HOX gene, the PL is considered an accessory muscle and not essential to the normal function of the flexion of the carpus, because its absence was not associated with loss of grip strength (ANGELINI JÚNIOR, ANGELINI, OLIVEIRA et al., 2012); thus, its tendon is used as a graft in countless surgical procedures (DAVIDSON, 1995; ATIYEH, HASHIM, HAMDAN et al., 1998; NAUGLE and FAUST, 1999).

Therefore, lately, this muscle has attracted the attention of clinicians. There is a growing interest in the existence of the muscle because its tendon is reported to be most frequently harvested for reconstructive plastic and hand surgery (MORAIS, GOMES, HELRIGLE et al., 2012).

According to Moore and Persaud (2004), the absence of one or more skeletal muscles is more frequent than is generally admitted. Commonly, only a single muscle is absent on one side of the body, or only part of the muscle ceases to develop. Occasionally, the same muscle or muscles may be absent on both sides of the body. In rare cases, there may be widespread deficiency in muscle development, leading to immobility in countless joints.

As described in a recent study (MORAIS, GOMES, HELRIGLE et al., 2012), skeletal muscles originate from the mesoderm of the myotomes of the somites. The myoblasts of hypaxial domain unite each other and originate the myotubes, which migrate to the periphery, forming striated skeletal muscle cells differentiated of appendicular muscles.
The absence of the PL has been described as ranging from a high of about $25 \%$ to $16 \%$ in white Caucasians (TROHA, BAIBAK and KELLEHER, 1990; THOMPSON, MOCKFORD and CRAN, 2001) to a low of $4 \%$ in mongoloids (SEBASTIN, PUHAINDRAN, LIM et al., 2005). An average of $14 \%$ absence has been universally accepted (MOORE, DALLEY and AGUR, 2011).

There is a conflict in literature regarding the symmetry of absence of PL and the gender in which absence is more common. Most studies indicate that the absence of PL is more common on the left side and in women (REIMANN, DASELER, ANSON et al., 1944; KAPOOR, TIWARI, KUMAR et al., 2008).

Recently, Morais, Gomes, Helrigle et al. (2012) conducted a study (740 subjects, 279 men and 461 women) to determinate the prevalence of unilateral and bilateral agenesis of PL. The results of this study showed that the bilateral presence was identified in $73.5 \%$, the absence on the left side in $7.8 \%$, on the right in $6.5 \%$ and bilateral absence was observed in $12.2 \%$ of subjects. Among women and men the percentage values was $9.3 \%, 7.3 \%, 13.1 \%$ and $5.4 \%, 5 \%$, $10.7 \%$, respectively to agenesis in left side, in right side and bilateral agenesis. The unilateral/bilateral agenesis was more frequent in women $(29.7 \%)$ than in men $(21.1 \%)$. Bilateral absence was $12.4 \%$ in right handed subjects and $9.1 \%$ in left handed subjects. Left and right handed subjects showed absence of muscle similar in both forearms.

In this context, an interesting study (542 subjects, 216 men and 326 women) (ERIC, KOPRIVCIC, VUCINIC et al., 2011) on the prevalence of the PL in relation to the hand dominance reveals the following results: right hand dominance was recorded in 452 (83.4\%) subjects while the left hand dominance was recorded in 90 (16.6\%) subjects. In right-handed subjects, PL tendon was absent on the right side in $24(5.3 \%)$ and on the left side in 50 (11.1\%) cases. In left-handed subjects, it was absent on the right side in $18(20 \%)$ and on the left side in $2(2.2 \%)$ cases. Bilateral absence of PL tendon was similar in both examined groups 
(25.1\% in the overall series, $24.3 \%$ in right-handed subjects, $28.9 \%$ in left-handed subjects).

In the anatomical literature, it is usually described that the RPL is more often on the left side. Nevertheless, the literature review shows that most of the cases described show a right side RPL (FAZAN, 2007).

Although there are countless reports (SCHUURMAN and VAN GILGS, 2000; RAWAT and JOHN, 2003; BABINSKI, VALENTE, SAVEDRA et al., 2008; MURABIT, GNARRA and MOHAMED, 2013) about the unilateral RPL, there are few reports of bilateral RPL. Giunta, Brunner and Wilhelm (1993) cited a rare case of a 21-year-old man suffered while working from symptoms of temporary median nerve compression in both forearms; this was caused by hypertrophy of RPL. The same way, Ogun, Karalezli and Ogun (2007), also described this rare variation in a 20 -year-old man, bilaterally.

According to the literature, a RPL may cause a compartment syndrome in the wrist area, carpal tunnel, and Guyon's syndrome. The described variation is also useful to the hand surgeon as a tendon graft, a tendon for transfer, or as an anatomical landmark for operations at this area (SALGADO, CANTÍN, INZUNZA et al., 2012).

We undertook this study with the aim of providing a more accurate report about the bilateral RPL, because of its interesting relationships with neuropathologies in adjacent structures. Moreover, this report is useful for academics, clinicians and surgeons who handle and have special interest in anatomical structures discussed in this work.

Finally, this report aims to provide a simple but multidisciplinary synthesis of the current knowledge concerning the morphogenesis, variation, and clinical significances of the PL, and to help promoting future studies in this area.

\section{References}

ANGELINI JÚNIOR, LCA., ANGELINI, FB., OLIVEIRA, BC., SOARES, SA., ANGELINI, LC. and CABRAL, RH. Utilização do tendão do músculo palmar longo em procedimentos cirúrgicos: estudo em cadáveres. Acta Ortopédica Brasileira, 2012, vol. 20, p. 226-229. PMid:24453608 PMCid:PMC3718403. http:// dx.doi.org/10.1590/S1413-78522012000400007

ATIYEH, BA., HASHIM, HA., HAMDAN, AM., KAYLE, DI. and MUSHARAFIEH, RS. Lower reconstruction and restoration of oral competence with dynamic palmaris longus vascularised sling. Archives of Otolaryngology - Head \& Neck Surgery, 1998, vol. 124, p. 1390-1392. PMid:9865766. http://dx.doi.org/10.1001/ archotol.124.12.1388

BABINSKI, MA., VALENTE, KMA., SAVEDRA, CMS., BURITY, CHF. and SABRÁ, AMC. Variação anatômica do músculo palmar longo associada a ausência do arco palmar superficial e compressão do canal de guyton. Acta Scientiae Medica, 2008, vol. 1, p. 54-58.

DAVIDSON, BA. Lip augmentation using the Palmaris longus tendon. Plastic Reconstrutive Surgery, 1995, vol. 95, p. 11081110. PMid:7732124. http://dx.doi.org/10.1097/00006534199505000-00026

ERIC, M., KOPRIVCIC, I., VUCINIC, N., RADIC, R., KRIVOCUCA, D., LEKSAN, I. and SELTHOFER, R. Prevalence of the palmaris longus in relation to the hand dominance. Surgical and Radiologic Anatomy, 2011, vol. 33, p. 481-484. PMid:21107568. http://dx.doi.org/10.1007/s00276-010-0751-0
FAZAN, VPS. Reversed palmaris longus muscle and median nerve relationships. Case report and literature review. Brazilian Journal of Morphological Sciences, 2007, vol. 24, p. 88-91.

GIUNTA, R., BRUNNER, U. and WILHELM, K. Bilateral reversed palmaris longus muscle--a rare cause of peripheral median nerve compression syndrome. Case report. Der Unfallchirurg, 1993, vol. 96, p. 538-540. PMid:8235674.

HICKS, J. and NEWELL, R. Supernumerary muscles in the pectoral and axillary region, and the nature of the axillary arches. Clinical Anatomy, 1997, vol. 10, p. 211-212.

KAPOOR, SK., TIWARI, A., KUMAR, A., BHATIA, R., TANTUWAY, V. and KAPOOR, S. Clinical relevance of palmaris longus agenesis: common anatomical aberration. Anatomical Science International, 2008, vol. 83, p. 45-48. PMid:18402087. http://dx.doi.org/10.1111/j.1447-073X.2007.00199.x

KHALEDPOUR, C. and SCHINDELMEISER, J. Atypical course of the rare accessory extensor carpi radialis muscle. Journal of Anatomy, 1994, vol. 184, p. 161-163. PMid:8157488 PMCid:PMC1259939.

KOO, CC. and ROBERTS, AH. The palmaris longus tendon. Another variation in its anatomy. Journal of Hand Surgery, 1997, vol. 22, p. 138-139. http://dx.doi.org/10.1016/S02667681(97)80043-5

MOORE, KL., DALleY, AF. and AGUR, AMR. Anatomia orientada para a clínica. 6. ed. Rio de Janeiro: Guanabara Koogan, 2011.

MOORE, KL. and PERSAUD, TVN. Embriologia clínica. 7. ed. Rio de Janeiro: Guanabara Koogan, 2004.

MORAIS, MA., GOMES, MS., HELRIGLE, C. and MALYSZ, T. Prevalence of agenesis of the palmaris longus muscle in Brazil and its clinics correlation. Journal of Morphological Science, 2012, vol. 29, p. $238-242$.

MURABIT, A., GNARRA, M. and MOHAMED, A. Reversed palmaris longus muscle: anatomical variant - case report and literature review. Canadian Journal of Plastic Surgery, 2013, vol. 21, p. 55-56. PMid:24431941 PMCid:PMC3891100.

NAUGLE, TCJR. and FAUST, DC. Autogeneous palmaris longus tendon as frontalis suspension material for ptosis correction in children. American Journal of Ophthalmology, 1999, vol. 127, p. 488489. http://dx.doi.org/10.1016/S0002-9394(99)00047-1

OGUN, TC., KARALEZLI, N. and OGUN, CO. The concomitant presence of two anomalous muscles in the forearm. Hand, 2007, vol. 2, p. 120-122. PMid:18780071 PMCid:PMC2527151. http://dx.doi.org/10.1007/s11552-007-9033-7

PAI, MM., PRABHU, LV., NAYAK, SR., MADHYASTHA, S., VADGAONKAR, R., KRISHNAMURTHY, A. and KUMAR, A. The palmaris longus muscle: its anatomic variations and functional morphology. Romanian Journal of Morphology and Embryology, 2008, vol. 49, p. 215-217. PMid:18516329.

PARK, MJ., NAMDARI, S. and YAO, J. Anatomic variations of the palmaris longus muscle. American Journal of Orthopedics, 2010, vol. 39 , p. 89-94.

RAOUF, HA., KADER, GA., JARADAR, A., DHARAP, A., FADEL, R. and SALEM, AH. Frequency of palmaris longus absence and its association with other anatomical variations in the egyptian population. Clinical Anatomy, 2013, vol. 26, n. 5, p. 572-577. PMid:20396682. http://dx.doi.org/10.1002/ca.22186

RAWAT, JS. and JOHN, B. Reverse palmaris longus muscle: a case report. Indian Journal of Orthopaedics, 2003, vol. 37, p. 33. 
REIMANN, AF., DASELER, EH., ANSON, BJ. and BEATON, LE. The palmaris longus muscle and tendon. A study of 1600 extremities. Anatomical Record, 1944, vol. 89, p. 495-505. http:// dx.doi.org/10.1002/ar.1090890408

SALGADO, G., CANTÍN, M., INZUNZA, O., MUNÕZ, A., SAEZ, J. and MACUER, M. Bilateral reversed palmaris longus muscle: a rare anatomical variation. Folia Mophologica, 2012, vol. 71 , p. 52-55.

SCHUURMAN, AH. and VAN GILGS, AP. Reversed palmaris longus muscle on MRI: report of four cases. European Radiology, 2000, vol. 10, p. 1242-1244. PMid:10939482. http:// dx.doi.org/10.1007/s003300000314

SEBASTIN, SJ., PUHAINDRAN, ME., LIM, AY., LIM, IJ. and $\mathrm{BEE}, \mathrm{WH}$. The prevalence of absence of the palmaris longus - a study in a Chinese population and a review of the literature. Journal of Hand Surgery, 2005, vol. 30, p. 525-527. PMid:16006020. http://dx.doi.org/10.1016/j.jhsb.2005.05.003
THOMPSON, NW., MOCKFORD, BJ. and CRAN GW. Absence of the palmaris longus muscle: a population study. Ulster Medical Journal, 2001, vol. 70, p. 22-24. PMid:11428320 PMCid:PMC2449224.

TROHA, F., BAIBAK, GJ. and KELLEHER, JC. Frequency of the palmaris longus tendon in North American Caucasians. Annals of Plastic Surgery, 1990, vol. 25, p. 477-478. PMid:2073079. http:// dx.doi.org/10.1097/00000637-199012000-00008

Received May 29, 2013

Accepted March 15, 2014 